\title{
Salinity problems in Mediterranean and island coastal aquifers in Spain
}

\author{
Emilio Custodio 1 \\ ${ }^{1}$ Royal Academy of Science (Spain). Emeritus Professor, Technical University of Catalonia, \\ Barcelona, Spain
}

\begin{abstract}
The Spanish coastal aquifers are often complex and bounded by or inside mountainous areas. Most of them are in Quaternary and Miocene littoral sediments or highly karstified carbonate formations, or in the case of the Canary Islands in volcanic formations. Along the Spanish Mediterranean coast and the Balearic and Canarian archipelagos coasts, 95 groundwater bodies have been identified, often including several aquifers. Some kind of marine salinization problems have been identified in 70 groundwater bodies ( 20 with generalized problems) but only a few aquifers have detailed, specific studies on sea water intrusion. Information on salinization is often based on scarce and occasional data.
\end{abstract}

Table1. Synthesis of the conditions on the significant Mediterranean and island aquifers in Spain (elaborated from SASMIE, 2017).

\begin{tabular}{|c|c|c|c|}
\hline Coastal aquifer & Salinization problems & Current situation & Action done \\
\hline Explanations & $\begin{array}{l}\text { WS, water supply } \\
I F, \text { impact on factories } \\
I A, \text { impact on agriculture } \\
\frac{G W, \text { groundwater }}{\frac{W R, \text { water resources }}{\text { IWRM, integrated WR management }}} \\
\text { CUAS, GW user's association }\end{array}$ & & $\begin{array}{l}\text { GWAR, GW abstract. reduction } \\
W I, \text { water importation } \\
R W, \text { relocation of wells } \\
\text { SWD, seawater desalination } \\
W A, \text { well abandonment } \\
\text { EI, efficiency improvement } \\
W W R, \text { waste water reclamation }\end{array}$ \\
\hline $\begin{array}{ll}\text { Tordera } & \text { Delta } \\
(\text { Catalonia }) & \\
\end{array}$ & Serious in the 1980s. WP, IF, IA & $\begin{array}{l}\text { Partial recovery; } \\
\text { New use }\end{array}$ & GWAR, SWDP \\
\hline $\begin{array}{ll}\text { Besós } & \text { Delta } \\
\text { (Barcelona) }\end{array}$ & Serious in the $1960 \mathrm{~s} . \mathrm{Ws}$, IF & $\begin{array}{l}\text { Reasonable } \\
\text { recovery; } \\
\text { Current partial } \\
\text { use }\end{array}$ & WA \\
\hline $\begin{array}{l}\text { Llobregat Delta } \\
\text { (Barcelona) }\end{array}$ & Serious in the 1970s. WS,IF, (IA) & $\begin{array}{l}\text { Under control } \\
\text { and managed. } \\
\text { Full use. Key } \\
\text { water reserve }\end{array}$ & $\begin{array}{l}\text { GWAR, IWRM, CUAS, WI, } \\
\text { SWD } \\
\text { Inj.. barrier. Artif. recharge, } \\
\text { WWR }\end{array}$ \\
\hline $\begin{array}{l}\text { Tarragona-Reus } \\
\text { (Catalonia) }\end{array}$ & $\begin{array}{l}\text { Serious in the } 1960 \mathrm{~s} \\
\text { WS, IF }\end{array}$ & Recovery & WA, WI \\
\hline $\begin{array}{l}\text { Vall d'Uixò (Plana } \\
\text { de Castelló) }\end{array}$ & Serious in the 1990 s. IA & Recovering & RW, EI \\
\hline $\begin{array}{l}\text { Marina } \\
\text { (Alicante) }\end{array}$ & Serious in the 1990s. WS & Partial recovery & SWD \\
\hline $\begin{array}{l}\text { Campo de Cartagena } \\
\text { (Murcia Region) }\end{array}$ & $\begin{array}{l}\text { Since the } 1990 \text { s } \\
\text { Brackish return irrigation flows. } \\
\text { Poor disposal of "debrackishing" plant } \\
\text { rejection }\end{array}$ & $\begin{array}{l}\text { Uncertain. } \\
\text { Water mixing, } \\
\text { "debrackishing". } \\
\text { Mar Menor } \\
\text { eutrophication }\end{array}$ & $\begin{array}{l}\text { Control of “debrackishing” } \\
\text { WWR, WI } \\
\text { Uncertain WI } \rightarrow \text { enhances } \\
\text { using brackish GW use }\end{array}$ \\
\hline $\begin{array}{l}\text { Campo de Níjar } \\
\text { (Almeria) }\end{array}$ & $\begin{array}{l}\text { Since the } 1980 \text { s. IA } \\
\text { Brackish natural GW (climatic) } \\
\text { Saline irrigation return flow. }\end{array}$ & Uncertain & $\begin{array}{l}\text { SWD (low use). } \\
\text { CUAS (local goals) } \\
\text { Mixing water }\end{array}$ \\
\hline $\begin{array}{l}\text { Campo de Dalías } \\
\text { (Almeria) }\end{array}$ & $\begin{array}{l}\text { Since the } 1990 \text { s. Currently serious. IA } \\
\text { Large greenhouse agricultural area in risk }\end{array}$ & $\begin{array}{l}\text { Uncertain } \\
\text { No clear } \\
\text { decisions }\end{array}$ & $\begin{array}{l}\text { CUAS (several), SWD, mixing } \\
\text { Incipient IWRM }\end{array}$ \\
\hline $\begin{array}{ll}\text { Mallorca } & \text { Island } \\
\text { (Balearic Is.) } & \\
\end{array}$ & $\begin{array}{l}\text { Serious since the } 1970 \mathrm{~s} \\
\text { WS, touristic areas supply }\end{array}$ & $\begin{array}{l}\text { Improvement } \\
\text { around }\end{array}$ & $\begin{array}{l}\text { WR, SWD } \\
\text { Local management }\end{array}$ \\
\hline
\end{tabular}




\begin{tabular}{|l|l|l|l|}
\hline & & $\begin{array}{l}\text { Palma de } \\
\text { Mallorca }\end{array}$ & \\
\hline $\begin{array}{l}\text { Menorca Island } \\
\text { (Balearic Is.) }\end{array}$ & Since the 1980s, in the two extremes & $\begin{array}{l}\text { Uncertain, risk } \\
\text { limited }\end{array}$ & SWD (not operative) \\
\hline $\begin{array}{l}\text { Eivissa-Ibiza } \\
\text { (Balearic Is.) }\end{array}$ & Serious since the 1980s & Uncertain & SWD (available not operative) \\
\hline $\begin{array}{l}\text { Gran Canaria Island } \\
\text { (Canary Is.) }\end{array}$ & Locally serious, since the 1970s & $\begin{array}{l}\text { Uncertain } \\
\text { No clear } \\
\text { decisions }\end{array}$ & $\begin{array}{l}\text { SWD, WR (partial), WA, } \\
\text { WWR } \\
\text { Local incipient IWRM }\end{array}$ \\
\hline $\begin{array}{l}\text { Tenerife Island } \\
\text { (Canary Is.) }\end{array}$ & Local, since the 1980s & $\begin{array}{l}\text { Excessive local } \\
\text { GW exploitation } \\
\text { restrictions }\end{array}$ & $\begin{array}{l}\text { SWD, WR, WWR } \\
\text { Restricted coastal aquifer use }\end{array}$ \\
\hline
\end{tabular}

The high human pressure near the coast for urban, industrial and tourism water supply and especially for irrigation has produced serious salinity problems in the coastal aquifers of Spain. These problems were acute in the 1950s in the Besós Delta and in the 1960s in the Llobregat Delta, near Barcelona. Afterwards, salinity problems showed up progressively in many other continental and island areas between 1970 and 1990. Up to 60 affected aquifers were identified in a survey carried out by the Geological and Mining Institute (MIMAM, 2000; López-Geta and Gómez-Gómez, 2008; Lópex-Geta and Fernández-Ruiz, 2012). Some of these salinization problems persist today while others have dwindled due to well abandonment after surface, reclaimed, and sea desalinated water was made available or to displacement of groundwater exploitation to areas further inland.

The public water administration, and the study and research institutes and the Academia made a great knowledge and monitoring effort on coastal aquifers in the period 1960-1990, and this is partly reflected in the SWIM and many other meeting proceedings, as summarized in SASMIE (2017), in which the existing scientific, technical and socioeconomic information has been summarized. But the effort decayed since two decades ago, so current monitoring and study activity is much less that what it was. Several older than 30 years coastal aquifer public monitoring networks exist, although there are periods without data. Data become more scarce and irregular since the early 2000s, with some exceptions, due to growing economic difficulties in the public water authorities. Groundwater users' are rarely involved in monitoring and paying for the expenses of the public organizations in charge.

\section{MANAGEMENT ACTIONS IN COASTAL AQUFIERS}

Public management action is dominantly directed to new infrastructures to bring new water to coastal areas with seawater intrusion instead of non-structural action. Infrastructural action is easier, allows continuing existing development and is well accepted by people, but is expensive and often involves direct, indirect and hidden subsidies. Non-structural action is more difficult, may include closing abstractions, redefining water rights, taxation and limitations, is less prone to be accepted by people, and needs trained personnel for management, which is scarce in old organizations with a high inertia, and not prone to adapt to new requirements, as is the case of the water authorities.

Import of water from other areas is done of southeastern Spain, mainly in the Segura Basin, but the availability of this water is not secured in dry years, even transactions at a price, as this involves inter-regional problems and some. The most expensive seawater desalination was adopted two decades ago in the Mediterranean and Balearic Islands and more than four decades ago in the Canary Islands. Reclamation of treated sewage water is developing and well established in the Segura Basin, in southeastern Spain, where about $95 \%$ of urban sewage water is used for irrigation and part of it is applied in the coastal area. Private action 
is limited and often it reduces to voluntarily closing salinized wells and drilling new, more expensive ones in areas farther from the coast, or to "debrackish" local coastal aquifer groundwater.

Under favorable circumstances, coastal aquifers are often used to abstract seawater to feed a part of the desalinations plants when hydrogeological conditions favor the possibility of obtaining the needed saline water flows Getting seawater from the aquifer avoid many of the hydraulic and water quality problems associated to direct uptake from the sea. However, illdesigned uptakes from the coastal aquifer may entrain a consumption of aquifer freshwater that mixes with seawater. This explains why the water authorities are not favorable to grant permits to abstract saline and brackish water to avoid increasing the consumption of continental water as well as saline affections to other groundwater users and to nearby wetland areas. Mixed water may also create problems to the plants if alkalinity and hardness increases, as well as to high $\mathrm{SO}_{2}$ concentration in some cases in the Canary Islands.

\section{ENVIRONMENTAL CONSEQUENCES OF COASTAL AQUIFIER DEVELOPMENT}

Many small- to medium-size groundwater related wetlands are found in coastal Spain, presenting a wide spectrum of natural and man-made typologies. They were and are significant for local economies, especially in semiarid areas, and they have to be preserved by law. But hydrological studies are scarce. The role of coastal groundwater discharge to the sea to maintain important ecosystems and their services has been rarely considered up to now. According to current water planning norms, a given coastal discharge has to be allowed and its amount is subtracted before assigning water resources to the different demands. The erroneous and biased thinking that groundwater discharge to the sea is a "loss of freshwater" is still deeply rooted in population and groundwater users living in water scarce areas, and this influences coastal groundwater management policies.

Negative externalities associated to coastal aquifer abstraction are not generally considered. Such are the deterioration of ecosystems and the salinization of other wells. In some cases, the outflow of high nitrate concentration groundwater creates serious eutrophication problems to coastal lagoons and littoral waters. This is currently a serious concern in the Mar Menor, near Cartagena, southeastern Spain, which is ecologically important, yield valuable ecological services and have around large tourism developments.

The numerous large coastal seawater desalination plants dispose safely their reject brines into the sea. This is not always the case of the up to 2000 small and medium size groundwater "debrakishing" plants applying membrane technology. This creates serious environmental problems in numerous places, mostly in the Campo de Cartagena-Mar Menor (Murcia) and in eastern Gran Canaria Island.

\section{ADMINISTRATIVE AND LEGAL ASPECTS OF COASTAL AQUIFER MANAGEMENT}

In the current Spanish water law and water planning regulations, seawater intrusion is mainly considered a water quality issue. Except in some water plans (Xùquer-Jucar and Catalonia), it is not taken into account that the freshwater flow that can be sustainably abstracted form a coastal aquifer is less than recharge. The relative scarce consideration of coastal aquifers in the Spanish water legislation is due to be local situations or affecting a small area of the 
territory the water authorities have to control and manage, even if they are densely inhabited and economically relevant areas. This situation is enhanced by the fact that despite being all water a public domain since 1985, in practice most of groundwater rights remain private as they correspond to previous legal regulations. The numerous actors in each case hinder the effective action capacity of water authorities.

There is not a clear policy on the application of the European Water Framework Directive further than trying that the groundwater bodies in bad status change into good status. In some cases, getting the good status implies a disproportionate effort, which may be not socially justified. So, less strict conditions are proposed, but not always supported by studies and a wide space and time vision of consequences and externalities.

\section{ECONOMIC ASPECTS OF COASTAL AQUIFER DEVELOPMENT}

In many Spanish coastal areas there is no other water resource than groundwater. When water is scarce in the coastal area, water importation from other areas and seawater desalination for urban and tourism supply and wastewater reclamation for irrigation are now common solutions, but at an increasing cost. The water cost at the place of use can be afforded by urban population, non-water intensive industry and tourism, but not by common farmers. Consequently, these farmers use as much as possible local resources, which often is groundwater abstracted by means of deep wells that are depleting aquifer water reserves or enhancing seawater intrusion. This situation is extremely difficult to be controlled and action is often politically unsupported. For urban and tourism supply, water of the general supply network is preferred to decrease quality hazards associated, although water from local coastal aquifers is often used a reserve to deal with water demand peaks and breakdowns. However this is mostly a private action as water planning do not generally take this into account

In much of the Spanish Mediterranean coastal area, common groundwater costs/prices at the production site range from 0.3 to $0.5 € / \mathrm{m}^{3}$, depending on circumstances. In the Canary Islands the most common prices are about $0.5 € / \mathrm{m}^{3}$, although in high water demand moments prices may exceed $1 € / \mathrm{m}^{3}$. These costs/prices are close to the farmers' willingness to pay for permanent supply, although they are higher for peak supplies to save a crop. In other cases costs are too high and crop fields become temporally or permanently idle.

Highly efficient irrigated crops, mostly to supply the European markets, can afford temporarily or permanently expensive water, such as desalinated seawater, every time more. But seasonal variability of water demand and the preferred use of local groundwater resources is the cause of the low use factor of most of the Mediterranean desalination plants. This increases the cost of produced water.

In the Spanish coastal areas, local or imported surface water may be cheaper than local groundwater, especially when only maintenance and operation costs are charged. But if all costs are taken into account, including transportation to the place of use and subsidies are cancelled, it is possible that the cost/price difference is reduced and even disappears. This may be also true even for desalinated seawater, especially when the water has to be pumped to high elevation and to faraway areas of use. In the case of "debrakished" groundwater, the cost of safe disposal of reject brines may cancel the economic advantages. This has been ignored until present. 
Efficient water use seems a sound economic goal but it is not as simple as there are many side and perverse effects. In many Spanish coastal aquifers recharge depends on infiltration of water coming from inner areas, as local return irrigation flows. Using allochtonous irrigation water more efficiently decreases recharge, which may seriously affect local coastal aquifer resources and the groundwater discharge into the sea that keeps the saline wedge to penetrating excessively and also maintain some special littoral environments.

A common practice in water-short intensive Spanish agricultural areas is producing every time the cheapest mixture of water with the appropriate salinity for the stage of the plants and to avoid soil deterioration. Water sources include available local or imported surface water, reclaimed wastewater, desalinated seawater and local groundwater. When groundwater or reclaimed water is brackish, a part of it may be "debrackished" with membrane technology.

What is paid for water in irrigated intensive agriculture is a small fraction of the total cost of the agricultural activity. However, as much of the needed inputs are out of the farmer's control, the water cost affects significantly the net margin that can be controlled by the farmer. Thus, the farmer looks for the cheapest water. Thus, water from the coastal aquifer is preferred if there cheap imported water available is not available, even if this implies mining groundwater reserves and an increase of salinization or the associated risk

\section{SOCIAL ASPECTS OF COASTAL AQUIFIER DEVELOPMENT}

Intensive exploitation of coastal aquifers has been the driver of economy in numerous areas. This allowed a more stable and evolved society, but with progressive cost increase and some environmental damage. A negative result is that in many places local economy depends excessively on crop irrigation. In successful areas, the high economic relevance achieved propitiates the false social and media feeling that these areas are essential to the country's economy and thus they deserve public non-refundable investment and support paid by others, and that the employment have to be secured at any price. This is reflected in subsidized action by governmental agencies, fostered by political pressure. Providing more water easies management, but sustainability is unclear and economically unsound if permanently done. This socio-economic model seems exhausted and a change of paradigm is needed. The change is demanded by the civil society, but still it is not in the public administration and politician minds. In fact, there is a strong reluctance to increase water supply tariffs and prices, although there is a consensus on non-increasing and even reducing agricultural irrigated areas. However, groundwater resources will continue to be abstracted in spite of serious problems in some areas (MASE, 2015).

The development of civil society institutions is still poor. The Academia has a moderate role and decreasing activity as economic resources are progressively dwindling due to the general economic crisis and to poor vision of medium- to long-term issues. This is especially true for the Spanish coastal aquifers.

Groundwater Users' Associations to protect their water resources are scarce in the Iberian Peninsula, even more in coastal aquifers. However, a successful groundwater users' association was launched in 1975 in the Llobregat delta, Barcelona, to join efforts with the water authority to reduce and control the conspicuous sea water intrusion in the aquifers (Custodio, 2012; Niñerola et al., 2009). This has been a successful enterprise that has converted the coastal aquifer in one of the key pieces of the integrated water resources 
management in the Barcelona Metropolitan Area. In this case, urban water suppliers and industrial enterprises dominate. Other 9 associations exist in coastal areas with variable goals and success. Forming them in agriculture dominated areas is difficult due to the large number of actors and the fact that owning a well right is a comparative advantage relative to other farmers, when surface water supply fails. These groundwater associations have to be different from the common irrigators associations, which are very numerous in Spain and deal mostly with the operation and management of public water concessions but not the water resource. In the Mediterranean and Balearic areas, groundwater water transactions are done in the private domain, but are local and of limited importance. However, In the Canary Islands, especially in Gran Canaria and Tenerife, water and private water rights trade was well established, approaching free markets. Currently they are dwindling due to the public offer of water at controlled prices. This public sector interference has positive and negative aspects, but it holds back private investments just when public economic resources are scarce. In Spain, the attempts to set specific taxes to compensate for environmental and other negative externalities have failed. Farmers do not pay the cost of management of groundwater. Current legal rules make difficult that these taxes have a final destination, so their effect and the public acceptability are doubtful. Moreover there is no experience on using the generated funds for spatial and time compensations

The cost of investments to avoid salinization and for management is normally not paid by the users, especially the farmers who use 60 to $80 \%$ of coastal water resources, depending on the area.

\section{REFERENCES}

Custodio, E. (2012). Low Llobregat aquifers: intensive development, salinization contamination and management. In: S. Sabater, A. Ginebreda, D. Barceló. The story of a Polluted Mediterranean River. The Handbook of Environmental Chemistry, 21: 27-50. DOI: 10.1007/698_2011_138.

López-Geta, J.A., Gómez-Gómez, J.D. (2008). La intrusión marina y su incidencia en los acuíferos españoles [Marine intrusión and its implications in Spanish aquifers]. Enseñanza de las Ciencias de la Tierra, Madrid, 153: 266-273.

López-Geta, J.A., Fernández Ruiz, L. (2012). Importancia de los acuíferos costeros en España y el papel del TIAC [Relevance of coastal aquifers in Spain and the role of TIAC]. In: IV TIAC (Technology of Intrusion in Coastal Aquifers), Instituto Geológico y Minero de España, II: 7-14.

MASE (2015). Aspectos hidrológicos, ambientales, económicos, sociales y éticos del consumo de reservas de agua subterránea en España [Hydrological, environmental, economic and ethical aspacts of groundwater reserves consumption in Spain]. Prepared by E. Custodio, for UPC and AQUALOGY-CETAQUA. Barcelona. UPC e-book: 1-487. http://hdl.handle.net/2117/111272.

MIMAM (2000). Libro blanco del agua en España [White book of water in Spain]. Ministerio de Medio Ambiente. Madrid.

Niñerola, J.M.; Queralt, E.; Custodio, E. (2009). Llobregat delta aquifer. In: Ph. Quevauviller, A-M. Fouillac, J. Grath, R. Ward (eds.), Groundwater Monitoring. John Wiley \& Sons: 289-301.

SASMIE (2017). Salinización de las aguas subterráneas en los acuíferos costeros mediterráneos e insulares españoles [Groundwater salinization in Mediterranean and island coastal aquifers in Spain]. Prepared by E. Custodio, for UPC and Suez Solutions-CETAQUA, Barcelona. UPC e-book. Barcelona: 1-852. http://hdl.handle.net/2117/111515 